\title{
AN ANALYSIS OF DETERMINANTS OF THE ADOPTION OF MOBILE HEALTH (MHEALTH)
}

\author{
Uma análise dos fatores que condicionam a adoção de Mobile Health (mHealth) \\ Un análisis de los factores que condicionan la adopción de Mobile Health (mHealth)
}

Nayra Leandro Miguel Martins ${ }^{1}$ | nayra.martins@islagaia.pt | ORCID: 0000-0001-7177-3375

Paulo Duarte² | pduarte@ubi.pt | ORCID: 0000-0001-8449-5474

José Carlos M. R. Pinho3 | jcpinho@eeg.uminho.pt | ORCID: 0000-0003-1829-0299

${ }^{1}$ ISLA-Instituto Politécnico de Gestão e Tecnologia, Vila Nova de Gaia, Portugal

2Universidade da Beira Interior, Research Centre in Business Sciences-NECE, Covilhã, Portugal

3Universidade do Minho, Centre for Research in Economics and Management-NIPE, Braga, Portugal

\section{ABSTRACT}

Given the increasing use of the Internet and mobile technologies, this study is pertinent as it seeks to analyze the factors that determine the adoption of Mobile Health (mHealth). To that end, the proposed conceptual model integrates the Unified Theory of Acceptance and Use of Technology (UTAUT2), Perceived Health Condition, eHealth Literacy and Perceived Health Competence as determinants of the adoption of mHealth. To answer the research questions, we used an online questionnaire administered to a non-probabilistic sample of Brazilian and Portuguese individuals who have or have not used mHealth. Data were analyzed using SPSS and SmartPLS3 software. The results indicate that adoption of mHealth is heavily impacted only by some UTAUT2 variables. The 'Performance Expectancy' dimension was found to heavily impact the adoption of mHealth among both users and non-users. KEYWORDS | Perceived health condition, eHealth literacy, perceived health competence, mHealth, UTAUT2.

\section{RESUMO}

Com a crescente utilização da internet e de tecnologias móveis, este estudo torna-se pertinente uma vez que busca analisar os fatores que condicionam a adoção de Mobile Health (mHealth). Para isso, o modelo conceitual proposto integra a Teoria Unificada de Aceitação e Uso da Tecnologia - Unified Theory of Acceptance and Use of Technology - Utaut2, Condição de Saúde Percebida, e-Literacia em Saúde e Competência de Saúde Percebida como determinantes da adoção do mHealth. Para responder às questões de pesquisa, utilizou-se um questionário on-line aplicado a uma amostra não probabilística de indivíduos brasileiros e portugueses que usaram e não usaram mHealth. Os dados foram analisados por meio dos softwares SPSS e SmartPLS3. Os resultados indicam que a adoção ao mHealth é fortemente impactada apenas por algumas variáveis da Utaut2. Entre os resultados, destaca-se o forte impacto da dimensão da "Expectativa de Desempenho" na adoção ao mHealth, tanto entre os utilizadores como entre os não utilizadores.

PALAVRAS-CHAVE / Condição de Saúde Percebida, E-Literacia em Saúde, Competência de Saúde Percebida, mHealth, Utaut2.

\section{RESUMEN}

Con el uso creciente de Internet y las tecnologías móviles, este estudio se vuelve pertinente a medida que busca analizar los factores que determinan la adopción de la Mobile Health (mHealth). Para ello, el modelo conceptual propuesto integra la teoría unificada de aceptación y uso de la tecnología UTAUT2, condición de salud percibida, literacia en e-salud y competencia de salud percibida como determinantes de la adopción de la mHealth. Para responder a las preguntas de investigación, se utilizó un cuestionario online aplicado a una muestra no probabilística de individuos brasileños y portugueses que usaron y no usaron $m$ Health. Los datos se analizaron utilizando los softwares SPSS y SmartPLS3. Los resultados indican que la adopción de $m$ Health es fuertemente afectada solo por algunas variables de la UTAUT2. Entre los resultados se destacan el fuerte impacto de la dimensión 'expectativa de rendimiento' en la adopción de la mHealth, tanto entre los usuarios como en los no usuarios.

PALABRAS CLAVE I Condición de salud percibida, literacia en e-salud, competencia de salud percibida, mHealth, UTAUT2. 


\section{INTRODUCTION}

According to Bernhardt, McClain, and Parrott (2004), the prevalence of eHealth (electronic health services) is growing and will continue to grow grounded on the advantages offered by internet-based health communication and on the fact that companies themselves are benefiting from its implementation. These and other Internetbased health communication characteristics may suggest why previous research indicates that the Internet has great potential for disseminating health information to the general public (Cotten \& Gupta, 2004).

According to Dwivedi, Shareef, Simintiras, Lal, and Weerakkody (2016), there is a need to restructure health care to keep it coherent and consistent with a dynamic, flexible, and mobile lifestyle, connected to an Information and Communication Technology (ICT) dominated society, and able to attract health care professionals and ICT consultants to design and implement professional mHealth systems.

According to the World Health Organization (WHO), Mobile Health or mHealth is defined as the medical practice with support for mobile devices, such as patient monitoring devices, smartphones, tablets, and other wireless devices, including the use of Short Message Service (SMS), 3 G and 4 G services, Global Positioning System (GPS) and Bluetooth. In the scientific literature, the term mHealth was first defined by Laxminarayan and Istepanian (2000) as "unwired e-med". In the last two decades, mHealth has evolved to become an important health communication channel for health care, health promotion, and health behavior monitoring (Steinhubl, Muse, \& Topol, 2015).

The widespread use of smartphones has increased the influence of mobile technologies on the experience and consumption of health services. mHealth thus becomes a market that emerges together with the expansion of mobile communication technologies (Sweileh et al., 2017). Regarding mHealth, the literature suggests that the use of mobile health applications serves several purposes (Riley et al., 2011), including improving preventive healthcare, limiting the growth of health costs, reducing unnecessary medical visits, and improving the information of users who have come to actively seek health information over the Internet using mobile devices (Fox \& Duggan, 2012). For Lee, Hoti, Hughes, and Emmerton (2015), health professionals are no longer the primary source of information, and the role of health service users is particularly relevant.

Kotz, Avancha, and Baxi (2009) stated in their study that social, behavioral, and technological issues involved in creating positive consumer beliefs leading to the adoption of mHealth systems are significantly different from traditional medical services in hospitals, and therefore this new context should be investigated.

In addition to information-seeking behaviors through smartphones, there has also been a significant increase in the number of available health applications (Fox \& Duggan, 2012; Kratzke \& Cox, 2012), since mHealth brings with it the promise of solving problems related to equal access to health care and also of providing a more effective response to new demands (Duque, Mamede, \& Morgado, 2017). Mobile health applications have the potential to reach heterogeneous audiences, such as doctors, patients, nurses, or even healthy people (Free et al., 2010). According to the "mHealth App Developer Economics 2016" report by Research2guidance (2016), the market for mHealth applications is still young and dynamic, but it will continue to grow due to the advantages obtained by companies, which attain substantial profits from its use. It is estimated that there are currently more than 350,000 applications available at the Apple Store and Google Play.

However, the adoption of mHealth technologies depends on people's willingness to embrace change, replacing old habits (Shareef, Kumar, \& Kumar, 2014). The existing literature suggests that the understanding of the general cognitive motivations that trigger the use of health applications is still limited. The use of mobile devices for health care is still a poorly documented and unexplored topic, as highlighted by Cameron, Ramaprasad, and Syn (2017). 
According to Carlos, Magalhães, Vasconcelos, Silva, and Brasil (2016), in Brazil, the use of technology in health care is still a challenge. There is a need for deepening health knowledge as well as implementing initiatives that seek a socially inclusive and economically competitive development model (Gadelha \& Costa, 2012).

A WHO (World Health Organization - WHO, 2019) report states that digital technologies offer concrete opportunities to address health system challenges, and thus offer the potential to improve the quality and extent of health services and practices. The report also highlights that digital health interventions can be used, for example, to facilitate targeted communication with users in order to expand contact coverage. Such interventions can also be targeted at health care professionals to give them more immediate access to clinical protocols through, for example, telemedicine meetings with other health care professionals. There are several ways in which digital technologies can be used to meet the needs of health systems, and these technologies continue to evolve due to the dynamic nature of the field.

Among the advantages of using mHealth, cited by Carlos et al. (2016), is the ability mobile devices have to assist users both in daily life and during rehabilitation or hospitalization. They can also assist health care providers during routine or emergency visits.

According to Biesdorf and Niedermann (2014), most people use health mobile technology applications because existing services do not meet their needs, or their quality is low. However, without an adequate understanding of the motivational and cognitive factors for the adoption and use of health applications, it becomes difficult to fully understand the use of these applications by individuals.

\section{LITERATURE REVIEW}

\section{Perceived Health Condition}

Research on prevention and health promotion widely recognizes that individual beliefs on health conditions are predictors of health behaviors (Becker \& Janz, 1984). Perceived health, defined by Neter and Brainin (2012) as health self-assessed by people in comparison to other individuals of their age and sex, has a strong normative component since it represents a way for people to become aware of the need to adopt specific behaviors. Rai, Chen, Pye, and Baird (2013) suggest that consumers who feel healthier are more open to experimenting with health innovations. These authors base their opinion on the evidence that those with little health perception may have strong pre-existing relationships with health service providers and establish therapeutic routines that may result in resistance to service alternatives and consumption options (Bitner, Brown, \& Meuter, 2000).

According to Shields and Shooshtari (2001), the change in lifestyle, physical condition, and psychological factors is valuable for the evolution of a more optimistic perspective on subjective health. In general, when a person assesses his or her health, he or she considers several factors that are often not identified in a physical assessment (Shields \& Shooshtari, 2001).

\section{Perceived Health Competence}

According to Smith, Wallston, and Smith (1995), Perceived Health Competence (PHC) represents the degree to which an individual feels able to effectively manage his or her health outcomes, as well as the perception and control over behavior and the ability to achieve goals. The Perceived Health Competence Scale (PHCS) was developed by 
Smith et al. (1995) to provide a measure of perceived competence at an intermediate level for which it combines expectations of outcomes and behaviors.

Bachmann et al. (2016) developed a study to evaluate the effect of Perceived Health Competence on a patient's belief in their ability to achieve health-related goals. These authors stated that patients with low Perceived Health Competence might be at risk of a decline in health-related quality of life after hospitalization and therefore are a potential target for counseling and other behavioral interventions.

\section{e-Literacy in health and mHealth adoption}

e-Literacy in health represents "the ability to seek, find, understand, and appraise health information from electronic sources and apply the knowledge gained to addressing or solving a health problem" (Norman \& Skinner, 2006 b, p. 2). According to Bodie and Dutta (2008), a high level of e-Literacy in health not only reflects the ability to use the Internet to find answers to health-related questions but also implies the ability to understand the data found, evaluate its truthfulness, discern the quality of different health websites, and use quality information to make informed health decisions.

Better digital health literacy helps patients use mobile health technologies more effectively. Research shows that patients with less health knowledge are less likely to adopt mHealth technology (Mackert, MabryFlynn, Champlin, Donovan, \& Pounders, 2016).

The main advantages of adopting mHealth are improved data exchange, time savings, reduced information loss, and also the collection of information from users without having to move from their home (Anantraman et al., 2002; Barrett, Strayer, \& Schubart, 2004; Koop \& Mösges, 2002). These advantages are not always obvious to users. The advantages that mHealth applications and services provide can be used by different medical specialties to improve the monitoring, prevention, and detection of disease. Thus, developing countries, where access to healthcare is difficult, seek to increase their effectiveness by integrating mHealth services into their healthcare systems (Déglise, Suggs, \& Odermatt, 2012).

\section{UTAUT and UTAUT2}

UTAUT theory was conceived by Venkatesh, Morris, Davis, and Davis (2003) to unify eight existing theories and models: Theory of Reasoned Action (TRA); Technology Acceptance Model (TAM); Motivational Model (MM); Theory of Planned Behavior (TPB); Combined TAM and TPB (C-TAM-TPB); Personal Computer Utilization Model (MPCU); Innovation Diffusion Theory (IDT); and Social Cognitive Theory (SCT). Such theories address the topic of how users accept and use technology (Venkatesh \& Morris, 2000; Venkatesh et al., 2003).

Since its original publication, the UTAUT has served as a reference model and has been applied in many studies on technologies in organizational and non-organizational environments (Dwivedi et al., 2016; EscobarRodríguez \& Carvajal-Trujillo, 2014; Tan, 2013). Riffai, Grant, and Edgar (2012) find that UTAUT provides a refined view of how the determinants of intent and behavior have evolved over time. However, there is a need for systematic research and theorization on the salient factors that would explain the application of digital technology in the consumer context, particularly within mHealth.

In order to strengthen UTAUT's ability to explain, Venkatesh, Thong, and Xu (2012) developed the UTAUT2, an even more complete model in which they changed some of the existing relationships in the original UTAUT's conceptualization and introduced new connections and constructs to make UTAUT2 useful within the framework 
of voluntary behavior, justifying its relevance within the framework of the adoption of mHealth. Thus, UTAUT2 will be used in this study, as it is more recent and more complete. Furthermore, it is more consistent with the proposal of the current study, which encompasses consumer behavior and the voluntary use of technology.

\section{Research Assumptions and Conceptual Model}

Based on the Utaut2 model and the dimensions of Perceived Health Condition, Perceived Health Competence, and e-Literacy in health, the conceptual model expressed in Figure 1 was formulated, with the following hypotheses discriminated with the respective theoretical support.

\section{Perceived Health Condition, e-Literacy in Health and Adoption of mHealth}

The Perceived Health Condition is not only related to the evaluation of physical health, but also to the incidence or prevalence of morbidity (which is the rate of a certain disease in relation to the total population studied) and mortality and, therefore, it is an important tool for evaluating health quality and peoples' lives (Leal, 2009). Based on a study with hypertensive people, Finkelstein (2000) suggests that the perception one has of his/her health influences the amount of health care resources used by confirming that there was a relationship between the number of visits to the doctor and the Perceived Health Condition.

In light of the above, the current study seeks to analyze whether individuals with worse self-perception tend to more easily adopt mHealth and develop eHealth-related skills. Thus, the following hypotheses are suggested:

H1: Perceived Health Condition positively influences e-Literacy in health.

H2: Perceived Health Condition positively influences the adoption of mHealth.

\section{Perceived Health Competence and Adoption of mHealth}

Smith et al. (1995) indicate that Perceived Health Competence is a predictor of intended and actual health behavior. Bachmann et al. (2016) developed a study among patients with cardiovascular disease and concluded that Perceived Health Competence predicts health behavior and health-related quality of life of patients, as well as health-related quality of life change after discharge. In the study by Smith et al. (1995), the perception of health competence was related to both intention and actual health behavior. Given the above, the following hypothesis is proposed:

H3: Perceived Health Competence positively influences the adoption of mHealth.

\section{e-Literacy in Health and Adoption of mHealth}

According to Cho, Park, and Lee (2014), health information obtained through health applications requires the competence of users to accurately understand the information accessed. Furthermore, there are cognitive differences in individuals' abilities to find and properly understand health information (Basu \& Dutta, 2008; Norman \& Skinner, $2006 \mathrm{~b}$ ). E-Health Literacy is closely related to an individual's cognition of his or her own ability to seek and understand online health information (Bodie \& Dutta, 2008; Norman \& Skinner, 2006a). Thus, it is conceivable to admit that a person with a high level of e-Literacy in health is more likely to perceive that he or she has a better capacity to use health applications, so the following hypothesis is proposed:

H4: e-Literacy in health positively influences the adoption of mHealth. 


\section{UTAUT2 and mHealth adoption}

In this section, each of UTAUT2's sub-dimensions are briefly characterized and their relationships with the adoption of mHealth are analyzed.

The first dimension to be analyzed refers to the expectation of performance, and it is defined as the degree to which an individual believes that the use of technology will help achieve performance gains in their tasks (Venkatesh et al., 2012). In the context of mobile banking, Luo, Li, Zhang, and Shim (2010) and Riffai et al. (2012) have concluded that performance expectation is a key factor for a user to accept the technology. Consequently, it is assumed that a user will adopt mHealth thinking about the benefits it can bring. In turn, the expectation of effort is defined as the degree of ease associated with using a system (Venkatesh et al., 2003). This construct reflects the perceived ease of use of an information system (Kuo \& Yen, 2009; Luarn \& Lin, 2005; Miltgen, Popovič, \& Oliveira, 2013) and has a positive impact on behavioral intention to use the system. Among the studies that analyze the impact of expected effort on the intention to adopt a technology, Dwivedi et al. (2016) emphasize that expected effort has a positive influence on behavioral intention to adopt mHealth.

Social influence is a direct antecedent of behavioral intention (Oliveira, Faria, Thomas, \& Popovič, 2014). Venkatesh et al. (2003) define social influence as the degree to which an individual realizes that it is important for others to believe that he or she uses the new technology or is in accordance with the expectations of others. People often become uncomfortable with uncertainty and, therefore, tend to interact with their social network to obtain an endorsement for their adoption decisions, thus suffering informative and normative social influences (Burkhardt \& Brass, 1990; Katz \& Tushman, 1979). However, it is also necessary to consider the facilitating conditions for the adoption of technology. These are defined as the degree to which an individual believes there is an organizational and technical infrastructure to support the use of the system (Venkatesh et al., 2003). Among the studies that analyze the impact of facilitating conditions on the intention to adopt a technology, Dwivedi et al. (2016) highlight that these have a positive influence on the behavioral intention to adopt mHealth. In light of the above, it is assumed that facilitating conditions have a positive influence on the adoption of mHealth.

Several articles demonstrate the influence of hedonic motivation on the intention and the actual use of that technology (Heijden, 2004; Thong, Hong, \& Tam, 2006). Particularly in the consumer context, it has also been shown that hedonic motivation influences the acceptance and use of technology (Brown \& Venkatesh, 2005; Childers, Carr, Peck, \& Carson, 2001). Similarly, several authors point out cost-related factors to explain consumer behavior (Chong, 2013; Dodds, Monroe, \& Grewal, 1991; Wei, Marthandan, Chong, Ooi, \& Arumugam, 2009). Agarwal, Wang, Xu, and Poo (2007), Ong, Poong, and Ng (2008), and Xin (2004) have shown that costs can have a negative relationship with consumers' intentions to adopt $3 \mathrm{G}$, a service that can be essential for mHealth adoption. Xin (2004) indicates that one of the reasons the SMS service is widely used by people is because of its low costs, so the price is predicted to negatively influence mHealth adoption.

As far as habit is concerned, it has been considered in many studies as a predictor of the use of a technology (Kim \& Malhotra, 2005; Kim, Malhotra, \& Narasimhan, 2005; Limayem, Hirt, \& Cheung, 2007). Limayem et al. (2007) showed the direct effect of habit on the continued use of technology and a more moderate effect of habit on the intent to use, as the stronger the habit, the less important the conscious intention to use the technology is.

Given the above, this study intends to test whether the seven UTAUT2 dimensions described influence the adoption of mHealth. For this, we propose the following general hypothesis and its sub hypotheses:

$\mathrm{H}_{5}$ : UTAUT2 dimensions influence mHealth adoption. 
The individual test of each dimension of UTAUT2 is performed to evaluate this hypothesis through the following sub hypotheses:

$\mathrm{H}_{5}$ a: Performance expectations positively influence mHealth adoption.

$\mathrm{H}_{5}$ b: Expected effort positively influences mHealth adoption.

$\mathrm{H}_{5} \mathrm{c}$ : Social influence positively influences mHealth adoption.

$\mathrm{H}_{5} \mathrm{~d}$ : Facilitating conditions positively influence mHealth adoption.

$\mathrm{H}_{5} \mathrm{e}$ : Hedonic motivation positively influences the adoption of mHealth.

$\mathrm{H}_{5}$ f: The price value negatively influences the adoption of mHealth.

H5g: Habit positively influences the adoption of mHealth.

Figure 1 graphically summarizes the conceptual model, as well as the hypothesized relationships under study in this research.

Figure 1. Initial Research Model

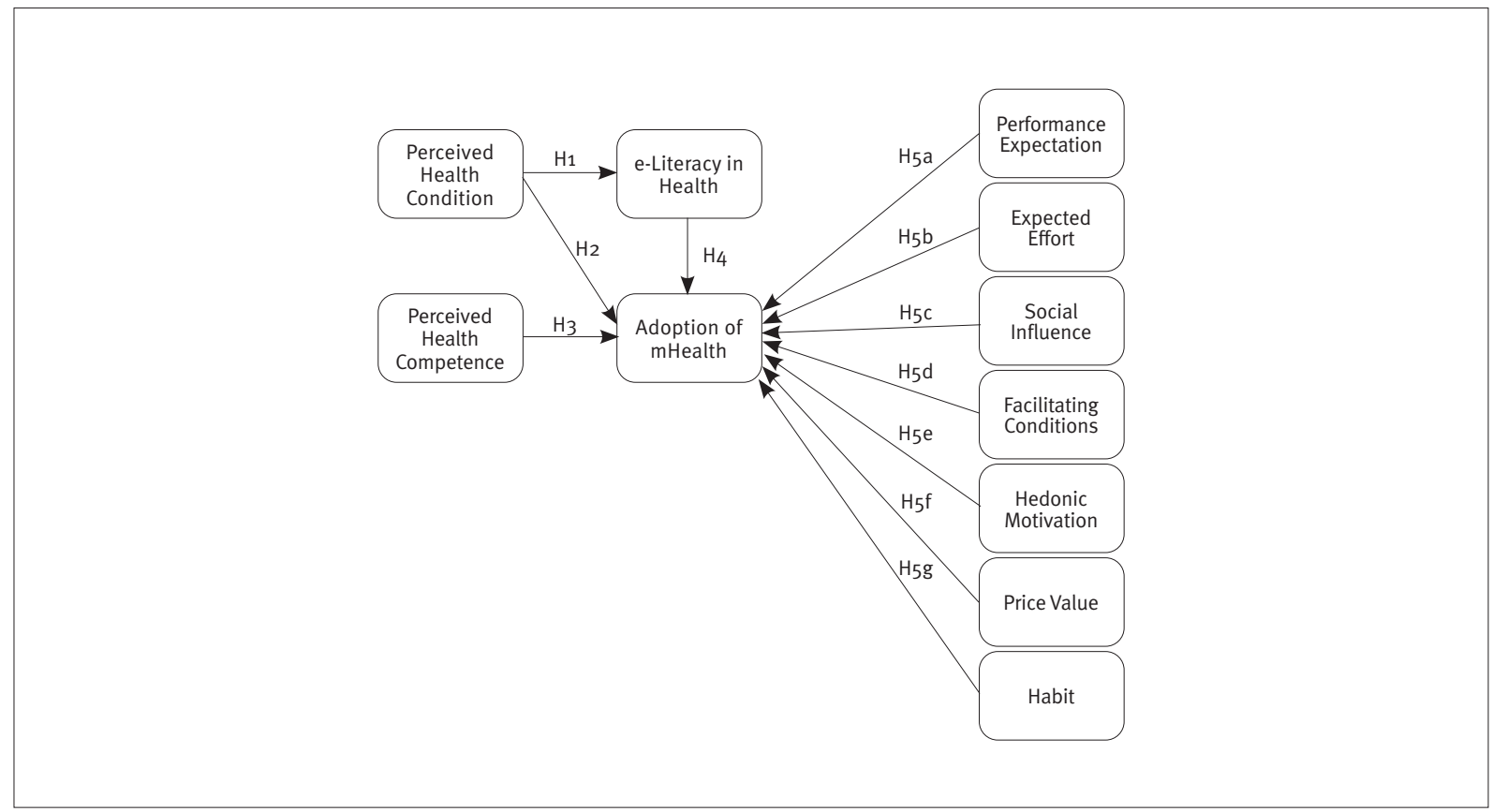

\section{METHOD}

\section{Data collection instrument and sample}

This study adopts a quantitative methodology. In this sense, a questionnaire was developed and applied to collect the data needed to evaluate the hypotheses regarding the factors that impact the adoption of mHealth among Portuguese and Brazilians. It was decided to compare these two nationalities since, due to historical factors, they present many similarities. Thus, the intention was to ascertain to what extent these similarities are 
perceptible concerning the use of mHealth technology. The questionnaire was subject to a pre-test with a group of Portuguese and Brazilian graduate students.

The pre-test was performed to uncover possible understanding problems that could bias the correct filling out of the questionnaire. Six pre-tests were performed in Portugal and six in Brazil. The pre-test respondents suggested changes in the wording of some items. In addition to these changes, a filter question was included to identify respondents who had already tried mHealth (group 1) and those who had never tried mHealth (group 2). This resulted in two groups, and subsequent analyses were conducted based on these two groups. Three pre-test respondents stated that whether or not they had experience with the technology interfered with how they interpreted the questions in the questionnaire. Thus, after the pre-test, it was deemed necessary to divide the sample into the above-mentioned groups to be able to identify whether the respondents' answers were based on their experience using mHealth or whether they responded based on a hypothetical situation.

The sample was obtained through a non-probabilistic sampling method, which implied the choice of the elements based on criteria defined by the investigator himself. Thus, invitations were sent to a large group of researchers' contacts containing the direct link to the questionnaire web page. The questionnaire was online through the LimeSurvey platform between April 2018 and July 2018. In the end, 326 valid answers were collected. Of this total, 120 respondents had already experienced mHealth, and 206 had not.

\section{MEASURES}

The review of the relevant literature allowed for the identification of the constructs and the scales for measurement that best fitted the research problem and that supported the development of the proposed conceptual model (Figure 1). The scales used in this study were based on previous research (e.g., Neter \& Brainin, 2012; Norman \& Skinner, 2006a; Smith et al., 1995; Tomás, Queirós, \& Ferreira, 2014; Venkatesh et al., 2012), but some indicators had to be adjusted for the current research context.

For the e-Literacy in Health construct, the validated version for Portuguese by Tomás et al. (2014) of the original scale proposed by Norman and Skinner (2006a) was used. The authors provide, upon request, the complete set of items used for this study. For evaluation of the items of the various constructs, a 7-point Likert scale anchored in (1)-Totally disagree and (7)-Fully agree was applied.

\section{RESULTS}

\section{Characterization of respondents}

Respondents were divided into two groups based on whether or not they had experienced mHealth. Group 1 comprised those who had experienced mHealth, and group 2 consisted of those who had not experienced mHealth. Among group 1, $73.3 \%$ were female, and $26.7 \%$ were male. In group 2, $65.5 \%$ were female, and $34.5 \%$ were male. Regarding age group, in group 1 , there is a predominance of two age groups, those aged between 18 and 29 years old and between 30 and 39 years old, totaling both $82.5 \%$ of the respondents. With regard to group 2, it can be observed that there is also the prevalence of two age groups, the one comprising individuals between 18 and 29 years of age and between 30 and 39 years of age, which make up $73.3 \%$ of the respondents. 
Regarding the nationality of the participants, the analysis revealed that in group 1, 36.7\% were Portuguese; $62.5 \%$ were Brazilian, and $0.8 \%$ were of another (Belgian) nationality. Regarding the nationality of participants in Group 2, there is a greater balance between the Portuguese and Brazilians, $48.5 \%$ and $49 \%$, respectively, $2.4 \%$ representing other nationalities (Angolan, English, and Uruguayan).

Regarding the origin of respondents, we look for significant differences between Portuguese or Brazilian participants. For this purpose, mean difference tests (t-test for independent samples) were performed, and the results indicated that there are no statistically significant differences between Portuguese and Brazilian respondents.

In the analysis of the several dimensions, it was verified that the scale for measure Perceived Health Competence (PHCS) presented some inconsistency, so we opted to perform an exploratory factor analysis (EFA), with oblique rotation in SPSS to evaluate the unidimensionality of the different indicators in the scale. It was defined that only factors with an eigenvalue higher than > 1 would be retained for analysis. Based on the analysis, two distinct factors were extracted. The first-factor groups items 1, 4, 5, and 8 . The secondfactor groups items 2, 3, 6, and 7. These two factors explain $61 \%$ of the total variance. The KMO (Measure of Sampling Adequacy) is considered good (0.80) and so is the respective Bartlett Sphericity Test (530.4; $\mathrm{pr}$ 0.001). It should be noted that there were no significant problems at the level of normality, homogeneity of variances, and linearity. Given the nature of the items, the first factor was called Health Competence, and the second factor, Inefficiency in Health. After this analysis, it was decided to subdivide the concept of PHCS into these two sub-dimensions, each one including four items. Based on the setting, the initial model was reformulated, and the final formulation is presented in Figure 2.

Partial Least Squares (PLS) SmartPLS 3.2.8 (Ringle, Wende, \& Becker, 2015) was used to test the model in Figure 2. PLS works very well in the presence of complex models, and it is robust in the face of deviations from normality assumption and small samples (Duarte \& Raposo, 2010). This method proposes that the analysis be done in two steps: 1) evaluation of the measurement model; 2) evaluation of the structural model.

\section{Figure 2. Final Research Model}

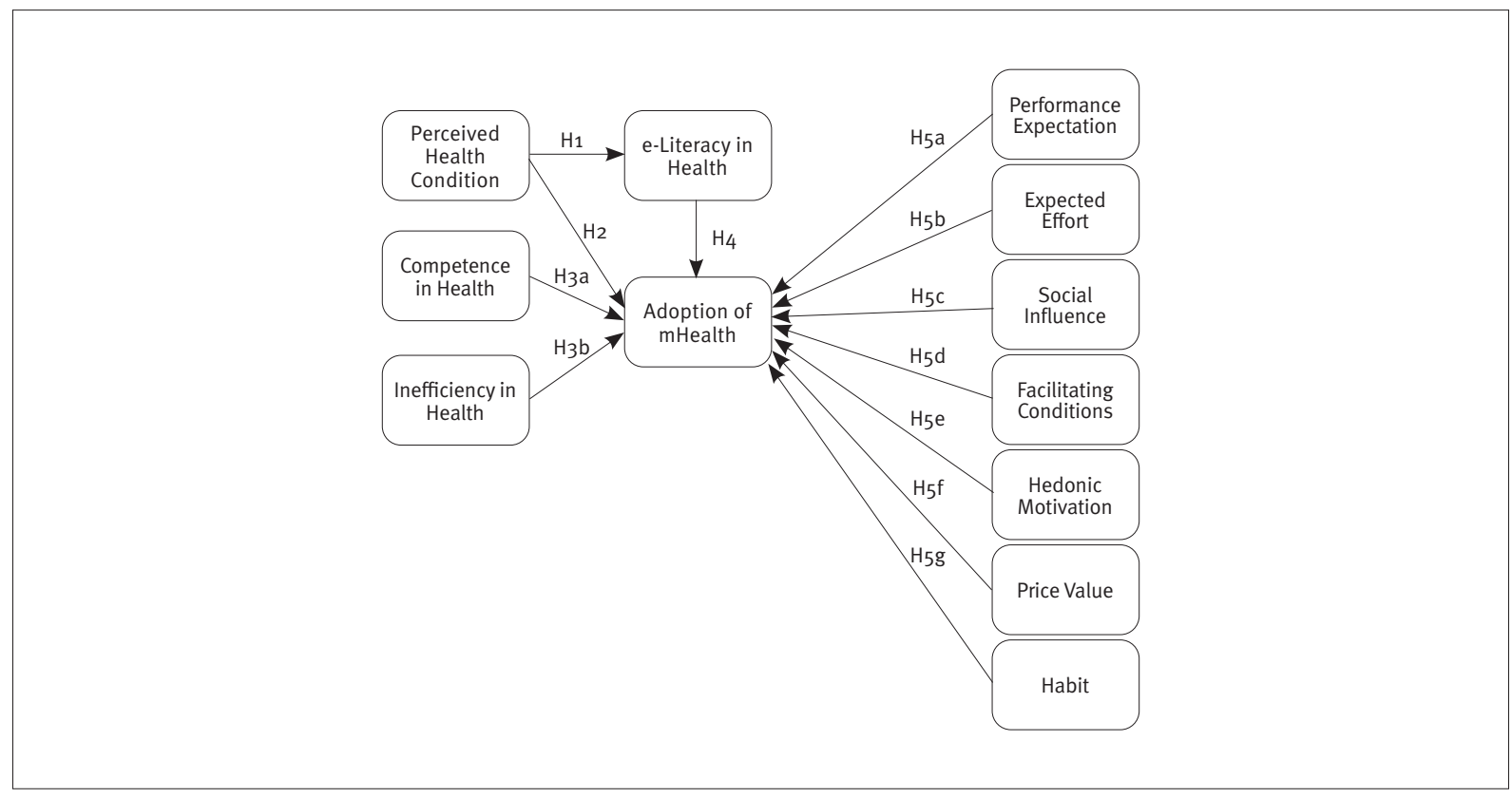




\section{Evaluation of the measurement model}

As far as the measurement model is concerned, the reliability analysis for each measurement scale for the two subgroups under analysis (group 1: those that had already tried mHealth; group 2: those that had not tried mHealth) was carried out in a first stage.

After the initial analysis for group 1 data, the indicators with factor loadings below 0.60 were removed. Then, to ensure the reliability of the different constructs, Cronbach's Alpha and the Composite Reliability index were calculated. The values for both criteria respect the minimum threshold of 0.70 (Fornell \& Larcker, 1981) and, as such, show a good level of internal consistency in the responses (Bagozzi \& Yi, 1988; Nunnally \& Bernstein, 1994). The same conclusion was drawn for group 2. Likewise, the Average Variance Extracted (AVE) is satisfactory for all constructs (above 0.50) (Bagozzi \& Yi, 1988) in both groups, with only one exception in group 2.

The discriminant validity indicates the degree of extension from which a given construct differs from the others. To assess discriminant validity two criteria were taken into account: 1) the indicators must have a greater weight in the respective construct than in all other constructs; 2 ) the square root of AVE, i.e., the values of the main diagonal of the table must be greater than all values (correlations) in the same line and column. As can be seen in Tables 1 and 2, both criteria are met for the two groups under analysis.

Table 1. Correlations and discriminant analysis of Group 1 (already experienced mHealth)

\begin{tabular}{|c|c|c|c|c|c|c|c|c|c|c|c|c|}
\hline Grupo 1 & CFacil & EDesem & EEsforço & Hábito & ISocial & $\begin{array}{l}\text { Ineficiência } \\
\text { em Saúde }\end{array}$ & $\begin{array}{c}\text { Motiv } \\
\text { Hed }\end{array}$ & $\begin{array}{l}\text { Condição } \\
\text { de Saúde }\end{array}$ & $\begin{array}{c}\text { Competência } \\
\text { em Saúde }\end{array}$ & Preço & $\begin{array}{l}\text { Adoção } \\
\text { mHealth }\end{array}$ & e-literacia \\
\hline CFacil & 0.754 & & & & & & & & & & & \\
\hline EDesem & 0.520 & 0.875 & & & & & & & & & & \\
\hline EEsforço & 0.675 & 0.361 & 0.842 & & & & & & & & & \\
\hline Hábito & 0.227 & 0.381 & 0.150 & 0.803 & & & & & & & & \\
\hline ISocial & 0.274 & 0.218 & 0.151 & 0.280 & 0.931 & & & & & & & \\
\hline $\begin{array}{l}\text { Ineficiência } \\
\text { em Saúde }\end{array}$ & 0.161 & -0.064 & 0.206 & -0.074 & -0.107 & 0.782 & & & & & & \\
\hline Motiv_Hed & 0.179 & 0.230 & 0.240 & 0.309 & 0.201 & -0.004 & 0.823 & & & & & \\
\hline $\begin{array}{l}\text { Condição de } \\
\text { Saúde }\end{array}$ & 0.198 & 0.192 & 0.276 & -0.016 & -0.072 & 0.520 & 0.148 & 0.784 & & & & \\
\hline $\begin{array}{l}\text { Competência } \\
\text { em Saúde }\end{array}$ & 0.178 & 0.114 & 0.177 & 0.196 & 0.006 & 0.375 & 0.241 & 0.536 & 0.747 & & & \\
\hline Preço & 0.189 & 0.042 & 0.310 & 0.103 & 0.235 & 0.073 & 0.279 & 0.155 & 0.156 & 0.702 & & \\
\hline $\begin{array}{l}\text { Adoção } \\
\text { mHealth }\end{array}$ & 0.437 & 0.705 & 0.328 & 0.505 & 0.298 & -0.138 & 0.437 & 0.047 & 0.153 & 0.137 & 0.819 & \\
\hline e-literacia & 0.392 & 0.250 & 0.423 & 0.163 & 0.026 & 0.219 & 0.118 & 0.369 & 0.434 & 0.046 & 0.217 & 0.829 \\
\hline
\end{tabular}


Table 2. Correlations and discriminant analysis of Group 2 (did not experience mHealth)

\begin{tabular}{|c|c|c|c|c|c|c|c|c|c|c|c|c|}
\hline Grupo 2 & $\begin{array}{l}\text { Cond } \\
\text { Facil }\end{array}$ & $\begin{array}{l}\text { Exp_ } \\
\text { Esfor }\end{array}$ & $\begin{array}{c}\text { Exp_ } \\
\text { desemp }\end{array}$ & Ineficiencia & $\begin{array}{l}\text { Infl_ } \\
\text { soc }\end{array}$ & $\begin{array}{c}\text { Motiv } \\
\text { Hed }\end{array}$ & PHC & PHCs & Preço & eHealth & hábito & mAdopt \\
\hline Cond_Facil & 0.728 & & & & & & & & & & & \\
\hline Exp_Esfor & 0.457 & 0.914 & & & & & & & & & & \\
\hline $\begin{array}{l}\text { Exp_- } \\
\text { desemp_ }\end{array}$ & 0.415 & 0.305 & 0.929 & & & & & & & & & \\
\hline Ineficiencia_ & 0.066 & 0.114 & -0.061 & 0.740 & & & & & & & & \\
\hline Infl_soc & 0.324 & 0.410 & 0.320 & -0.051 & 0.961 & & & & & & & \\
\hline Motiv_Hed & 0.284 & 0.537 & 0.246 & 0.040 & 0.455 & 0.950 & & & & & & \\
\hline PHC & 0.095 & 0.070 & 0.055 & 0.461 & -0.071 & 0.019 & 0.809 & & & & & \\
\hline PHCs & 0.135 & 0.125 & 0.112 & 0.135 & 0.045 & 0.156 & 0.412 & 0.804 & & & & \\
\hline Preço & 0.117 & 0.304 & 0.179 & -0.038 & 0.408 & 0.556 & 0.010 & 0.151 & 0.803 & & & \\
\hline eHealth & 0.251 & 0.300 & 0.109 & 0.109 & 0.021 & 0.106 & 0.165 & 0.132 & 0.046 & 0.831 & & \\
\hline hábito & 0.255 & 0.114 & 0.299 & -0.111 & 0.234 & 0.169 & -0.027 & 0.112 & -0.012 & 0.067 & 0.935 & \\
\hline mAdopt & 0.368 & 0.231 & 0.717 & -0.155 & 0.376 & 0.265 & -0.014 & 0.162 & 0.161 & 0.003 & 0.353 & 0.852 \\
\hline
\end{tabular}

Based on the results, it is possible to affirm that most of the psychometric tests for the different scales of measurement show unidimensionality, consistency, and conceptual robustness.

\section{Evaluation of the structural model}

The analysis of the significance of the structural coefficients based on the $t$-test and $R^{2}$ values was performed to assess the proposed hypotheses. For this purpose, we used the bootstrapping procedure with 5000 samples (Table 3).

\section{Discussion and Final Considerations}

The main focus of this research was to propose a model that would help to understand the most important background to the adoption of mHealth. For this purpose and to ensure diversity, we chose to include respondents of two nationalities, noticing that there are no statistically significant differences associated with this factor. Likewise, it was considered crucial to distinguish the respondents who had or had not tried (or adopted) a mHealth platform. Therefore, we opted to divide respondents between those who had already tried mHealth (group 1) and those who had not (group 2). The data analysis was performed separately for the two groups. In general, based on the analysis performed, we can conclude that in group 1, four of the 12 hypotheses tested were confirmed, while in group 2, five of the 12 hypotheses were confirmed. 
Table 3. Result of the Hypothesis Test

\begin{tabular}{|c|c|c|c|c|c|c|}
\hline \multirow[b]{2}{*}{ Paths } & \multicolumn{3}{|c|}{$\begin{array}{l}\text { Experienced mHealth } \\
\text { (group 1) }\end{array}$} & \multicolumn{3}{|c|}{$\begin{array}{l}\text { Did not experience mHealth } \\
\qquad \text { (group 2) }\end{array}$} \\
\hline & $\begin{array}{l}\text { Direct } \\
\text { Effects }\end{array}$ & $\begin{array}{c}\text { t-Value } \\
\text { (bootstrap) }\end{array}$ & Supported & $\begin{array}{l}\text { Direct } \\
\text { Effects }\end{array}$ & $\begin{array}{c}\text { t-Value } \\
\text { (bootstrap) }\end{array}$ & Supported \\
\hline H1: CSP.... e-Literacia & $0.36^{\star * *}$ & $5 \cdot 34$ & Yes & $0.16^{*}$ & 2.10 & Yes \\
\hline $\mathrm{H}_{2}$ : CSP .... ; ad_mHealth & 0.10 & 1.35 & No & -0.02 & 0.40 & No \\
\hline Нза: COMP_S ..... ad_mHealth & 0.06 & 0.68 & No & 0.10 & 1.16 & No \\
\hline H3b: Inefic_S $\ldots .$. ad_mHealth & 0.07 & 0.85 & No & $0.10^{\star}$ & 1.65 & Yes \\
\hline $\mathrm{H}_{4}$ : e-Literacia $\cdots . .$. ? ad_mHealth & 0.02 & 0.23 & No & -0.07 & 1.16 & No \\
\hline $\mathrm{H}_{5} \mathrm{a}:$ ED $\cdots$; ad_mHealth & $0.54^{\star \star \star}$ & 6.56 & Yes & $0.61^{\star \star \star}$ & 11.3 & Yes \\
\hline H5b: EE $\cdots$ ad_mHealth & 0.02 & 0.36 & No & -0.05 & 0.80 & No \\
\hline $\mathrm{H}_{5 \mathrm{C}}: \mathrm{IS} \ldots$ ? ad_mHealth & 0.04 & 0.61 & No & $0.13^{*}$ & 1.96 & Yes \\
\hline $\mathrm{H}_{5} \mathrm{~d}: \mathrm{CF} \ldots$ ? ad_mHealth & 0.05 & 0.61 & No & 0.07 & 1.15 & No \\
\hline $\mathrm{H}_{5} \mathrm{e}: \mathrm{MH} \cdots \cdots$ ? ad_mHealth & $0.22^{\star \star \star}$ & 3.35 & Yes & 0.07 & 0.94 & No \\
\hline $\mathrm{H}_{5} \mathrm{f}: \mathrm{VP} \ldots \ldots . \mathrm{s}$ ad_mHealth & 0.01 & 0.12 & No & -0.05 & 0.47 & No \\
\hline $\mathrm{H}_{5 \mathrm{~g}}: \mathrm{Hab} \cdot \cdots$ ? ad_mHealth & $0.18^{\star}$ & 2.16 & Yes & $0.09^{*}$ & 1.70 & Yes \\
\hline
\end{tabular}

Based on t (1000); * p < 0.05 (1,645); ** p <0.01 (2,327); *** $p<0.001$ (3,092); unilateral.

Caption: CSP = Perceived Health Condition; e-Literacia = e-Literacy in Health; ad_mHealth = Adoption of mHealth; COMP_S = Competence in Health; Inefic_S = Inefficiency in Health; $E D=$ Performance Expectation; $E E=$ Expected Effort; IS = Social Influence; $C F=$ Facilitating Conditions; $M H=$ Hedonic Motivation; $\mathrm{VP}=$ Price Value; $\mathrm{Hab}=$ Habit.

Based on the results, it can be concluded that, in general, the adoption of mHealth ( $\mathrm{AmH})$ is strongly impacted by selected UTAUT2 variables, although not all. This conclusion applies equally to those respondents who had previously adopted mHealth and those who had not. Among the variables with the greatest impact, performance expectations (ED) stands out. This result is true both for respondents who have already experienced mHealth (group 1) and for those who have never experienced it (group 2). This finding highlights a distinction between ease of use and utility. Although high health literacy is strongly correlated with ease of use, the same does not happen with utility and performance expectations. Although patients can use mHealth tools, they need to consider them relevant or useful for improving health.

The same applies to hedonic motivation $(\mathrm{MH})$ and habit $(\mathrm{H})$. According to our study, these three variables (performance expectations, hedonic motivation, and habit) from UTAUT2 play an important role in the adoption 
of mHealth, particularly for respondents who have already experienced this technology (group 1). Accordingly, we can state that hypothesis 5 (which groups the different sub-dimensions of UTAUT2) is only partially supported.

For the group of respondents who have not yet experienced the mHealth platform (group 2), the most relevant variables were expected performance (identical to group 1), social influence, and habit (identical to group 1). As in the previous analysis, we could state that hypothesis 5 is also only partially supported.

In addition to the UTAUT2 variables, this study went a little further and tried to see if there would be any influence from a set of health-related variables such as Perceived Health Condition, Perceived Health Competence (later subdivided into health competence and health inefficiency), and e-Health Literacy on the adoption of the mHealth platform. From this analysis, it was possible to verify that the Perceived Health Condition has a significant impact on e-Health Literacy, thus confirming hypothesis 1 . This result is verified for both groups. The remaining hypotheses of group $1\left(\mathrm{H}_{2}, \mathrm{H}_{3} \mathrm{a}, \mathrm{H}_{3} \mathrm{~b}\right.$, and $\left.\mathrm{H}_{4}\right)$ were not confirmed by the data. Only hypothesis $\mathrm{H}_{3} \mathrm{~b}$ was confirmed for group 2. The results suggest, albeit timidly, that health ICT developers should seek to make these tools more user-friendly and navigable for patients with lower levels of e-Literacy in health since more literate health users also appreciate simplicity, and this influences the perception of performance. Thus, an approach to interventions designed for users with lower health literacy, focusing on design and usability for users with less mHealth experience, is beneficial for everyone.

The final considerations of this research allow us to infer that the new opportunities offered by the new mobile technologies do not seem to have been fully exploited so far. Mapping the evolution of the field allows for a better understanding of its strengths and weaknesses in addition to suggesting the steps for the development of future research. In view of the results, it is possible to state that the mHealth market still has a long way to go to reach a larger portion of society. In the future, health care ICT developers and industry professionals should focus more closely on their target audiences, ensuring that the technologies are designed for their actual use.

Still, the need to understand how eHealth literacy relates to the adoption and use of mHealth applications persists. It is needed to ensure that all users can access the full benefits of technological advances, although the privacy of health information needs to be secured so that users are willing to get involved and trust organizations and providers of mHealth solutions. Despite mobile health is often praised as a useful tool for improving patient involvement, it may not achieve this goal on its own, and tactics aimed at educating the potential user to promote meaningful use of mHealth must be used. This can be achieved by adopting multi-faceted user and patient engagement strategies in order to identify the knowledge and skills needed to use and understand the benefits of managing their health data. These findings can be used by academics, government, policymakers, and industry companies to maximize acceptance and use of mHealth services.

\section{Limitations and Future Studies}

The limitations of this study are mainly related to the nature of the sample and sampling technique, which make it difficult to obtain more robust data and, above all, make it impossible to generalize the conclusions of this study, despite the effort to ensure the diversity and comprehensiveness of respondents. These limitations imply that the results should be analyzed with caution and that they should be restricted to the conditions under which the study was conducted.

Furthermore, since the population of the present study was chosen using the convenience criterion, it would be interesting, for example, to include in the questionnairethe area of knowledge and profession of the 
respondents as well as other factors that may have had an impact on the extent to which the participant was exposed to technology. This suggestion for future research becomes necessary because if a group was composed mainly of individuals more likely to use an application, this could influence the results and the conclusions.

In this sense, it is also suggested that future research should consider using not only a larger and probabilistic sample, but also moderators (gender, age, and experience) in the model, since the latter were not used in this research and maybe interesting in future research, given the relevance demonstrated in previous studies (Venkatesh et al., 2003; Venkatesh et al., 2012).

\section{ACKNOWLEDGMENTS}

1. This research was carried out during a doctorate program funded by the Fundação CAPES - Ministry of Education of Brazil, through a scholarship.

2. The authors would like to thank NECE - Research Unit in Business Sciences funded by the Multiannual Funding Programme of R\&D Centres of FCT - Fundação para a Ciência e a Tecnologia, under the project UIDB/04630/2020.

\section{REFERENCES}

Agarwal, N. K., Wang, Z., Xu, Y., \& Poo, D. C. C. (2007). Factors affecting $3 \mathrm{G}$ adoption: An empirical study. PACIS 2007 Proceedings, Paper 3, 256-270. Retrieved from http://aisel. aisnet.org/pacis2007/3

Anantraman, V., Mikkelsen, T., Khilnani, R., Kumar, V. S., Pentland, A., \& Ohno-Machado, L. (2002). Open source handheld-based EMR for paramedics working in rural areas. AMIA - Annual Symposium Proceedings. AMIA Symposium, 12 16. doi: D020002441[pii]

Bachmann, J. M., Goggins, K. M., Nwosu, S. K., Schildcrout, J. S., Kripalani, S., \& Wallston, K. A. (2016). Perceived health competence predicts health behavior and health-related quality of life in patients with cardiovascular disease. Patient Education and Counseling, 99, 2071-2079. doi: 10.1016/j. pec.2016.07.020

Bagozzi, R. P., \& Yi, Y. (1988). On the evaluation of structural equation models. Journal of the Academy of Marketing Science, 16(1), 74-94. doi: 10.1007/bfo2723327

Barrett, J. R., Strayer, S. M., \& Schubart, J. R. (2004). Assessing medical residents' usage and perceived needs for personal digital assistants. International Journal of Medical Informatics, 73(1), 25-34. doi: 10.1016/j.ijmedinf.2003.12.005

Basu, A., \& Dutta, M. J. (2008). The relationship between health information seeking and community participation: The roles of health information orientation and efficacy. Health Communication, 23(1), 70-79. doi: $10.1080 / 10410230701807121$
Becker, M. H., \& Janz, N. K. (1984). The health belief model: A decade later. Health Education Quarterly, 11(1), 1-47. doi: $10.1177 / 109019818401100101$

Bernhardt, J. M., McClain, J., \& Parrott, R. L. (2004). Online health communication about human genetics: Perceptions and preferences of internet users. CyberPsychology and Behavior, 7(6), 728-733. doi: 10.1089/cpb.2004.7.728

Biesdorf, S., \& Niedermann, F. (2014). Healthcare's digital future. McKinsey \& Company.

Bitner, M. J., Brown, S. W., \& Meuter, M. L. (2000). Technology infusion in service encounters. Journal of the Academy of Marketing Science, 28(1), 138-149. doi: 10.1177/0092070300281013

Bodie, G. D., \& Dutta, M. J. (2008). Understanding health literacy for strategic health marketing: eHealth literacy, health disparities, and the digital divide. Health Marketing Quarterly, 25(1-2), 175-203. doi: 10.1080/07359680802126301

Brown, S. A., \& Venkatesh, V. (2005). Model of adoption and technology in households: A baseline model test and extension incorporating household life cycle. MIS Ouarterly, 29(3), 399-426. doi: 10.2307/25148690

Burkhardt, M. E., \& Brass, D. J. (1990). Changing patterns or patterns of change: The effects of a change in technology on social network structure and power. Administrative Science Quarterly, 35(1), 104-127. doi: 10.2307/2393552 
Cameron, J. D., Ramaprasad, A., \& Syn, T. (2017). An ontology of and roadmap for mHealth research. International Journal of Medical Informatics, 100, 16-25. doi: 10.1016/j. ijmedinf.2017.01.007

Carlos, D. A. O., Magalhães, T. O., Vasconcelos, J. E., Filho, Silva, R. M., \& Brasil, C. C. P. (2016, setembro). Concepção e avaliação de tecnologia mHealth para promoção da saúde vocal. Risti Revista Ibérica de Sistemas e Tecnologias de Informação, (19), 46-6o. doi: 10.17013/risti.19.46-60

Childers, T. L., Carr, C. L., Peck, J., \& Carson, S. (2001). Hedonic and utilitrian motivations for online retail shopping behavior. Journal of Retailing, 77, 511-535. doi: 10.1016/S00224359(01)00056-2

Cho, J., Park, D., \& Lee, H. E. (2014). Cognitive factors of using health apps: Systematic analysis of relationships among health consciousness, health information orientation, eHealth literacy, and health app use efficacy. Journal of Medical Internet Research, 16(5), e125. doi: 10.2196/jmir.3283

Chong, A. Y. L. (2013). A two-staged SEM-neural network approach for understanding and predicting the determinants of m-commerce adoption. Expert Systems with Applications, 40(4), 1240-1247. doi: 10.1016/j.eswa.2012.08.067

Cotten, S. R., \& Gupta, S. S. (2004). Characteristics of online and offline health information seekers and factors that discriminate between them. Social Science and Medicine, 59(9), 1795-1806. doi: 10.1016/j.socscimed.2004.02.020

Déglise, C., Suggs, L. S., \& Odermatt, P. (2012). Short Message Service (SMS) applications for disease prevention in developing countries. Journal of Medical Internet Research, 14(1), e3. doi: 10.2196/jmir.1823

Dodds, W. B., Monroe, K. B., \& Grewal, D. (1991). Effects of price, brand, and store information on buyers' product evaluations. Journal of Marketing Research, 28(3), 307-319. doi: $10.2307 / 3172866$

Duarte, P. A. O., \& Raposo, M. L. B. (2010). A PLS model to study brand preference: An application to the mobile phone market. In Handbook of partial least squares, 449-485. Springer, Berlin, Heidelberg. doi: 10.1007/978-3-540-32827-8_21

Duque, C., Mamede, J., \& Morgado, L. (2017). Iniciativas de mHealth em Portugal. In: CISTI 2017: 12th Iberian Conference on Information Systems and Technologies. 1-6, IEEE. doi: 10.23919/CISTI.2017.7975803

Dwivedi, Y. K., Shareef, M. A., Simintiras, A. C., Lal, B., \& Weerakkody, V. (2016). A generalised adoption model for services: A cross-country comparison of mobile health (m-health). Government Information Quarterly, 33(1), 174-187. doi: $10.1016 /$ j.giq.2015.06.003

Escobar-Rodríguez, T., \& Carvajal-Trujillo, E. (2014). Online purchasing tickets for low cost carriers: An application of the unified theory of acceptance and use of technology (Utaut) model. Tourism Management, 43, 70-88. doi: 10.1016/j. tourman.2014.01.017

Finkelstein, M. M. (2000). Hypertension, self-perceived health status and use of primary care services. Canadian Medical Association Journal, 162(1), 45-46. Retrieved from: https:// www.cmaj.ca/content/162/1/45/tab-article-info
Fornell, C., \& Larcker, D. F. (1981). Structural equation models with unobservable variables and measurement error: Algebra and statistics. Journal of Marketing Research, 18(3), 382. doi: $10.2307 / 3150980$

Fox, S., \& Duggan, M. (2012). Mobile Health 2012. Pew Research Center's Internet \& American Life Project. Retrieved from http:// www.pewinternet.org/2012/11/08/mobile-health-2012/

Free, C., Phillips, G., Felix, L., Galli, L., Patel, V., \& Edwards, P. (2010). The effectiveness of M-health technologies for improving health and health services: a systematic review protocol. BMC Research Notes, 3, 250. doi: 10.1186/17560500-3-250

Gadelha, C. A. G., \& Costa, L. S. (2012). Saúde e desenvolvimento no Brasil: Avanços e desafios. Revista de Saúde Pública, 46(1), 13-20. doi: 10.1590/s0034-89102012005000062

Heijden, H. Van der. (2004). User acceptance of hedonic information systems. MIS Quarterly, 28(4), 695-704. doi: $10.2307 / 25148660$

Katz, R., \& Tushman, M. (1979). Communication patterns, project performance, and task characteristics: An empirical evaluation and integration in an R\&D setting. Organizational Behavior and Human Performance, 23(2), 139-162. doi: 10.1016/0030-5073(79)90053-9

Kim, S. S., \& Malhotra, N. K. (2005). A longitudinal model of continued IS use: An integrative view of four mechanisms underlying postadoption phenomena. Management Science, 51(5), 741-755. doi: $10.1287 / \mathrm{mnsc} .1040 .0326$

Kim, S. S., Malhotra, N. K., \& Narasimhan, S. (2005). Research note - Two competing perspectives on automatic use: A theoretical and empirical comparison. Information Systems Research, 16(4), 418-432. doi: 10.1287/isre.1050.0070

Koop, A., \& Mösges, R. (2002). The use of handheld computers in clinical trials. Controlled Clinical Trials, 23(5), 469-480. doi: 10.1016/S0197-2456(02)00224-6

Kotz, D., Avancha, S., \& Baxi, A. (2009). A privacy framework for mobile health and home-care systems. Proceedings of the First ACM Workshop on Security and Privacy in Medical and Home-Care Systems - Spimacs '09, November 1, 1-12. doi: $10.1145 / 1655084.1655086$

Kratzke, C., \& Cox, C. (2012). Smartphone technology and apps: Rapidly changing health promotion. International Electronic Journal of Health Education, 15, 72-82. doi: ISSN-1529-1944

Kuo, Y. F., \& Yen, S. N. (2009). Towards an understanding of the behavioral intention to use $3 \mathrm{G}$ mobile value-added services. Computers in Human Behavior, 25(1), 103-110. doi: 10.1016/j. chb.2008.07.007

Laxminarayan, S., \& Istepanian, R. S. H. (2000). Unwired E-MED: The next generation of wireless and Internet telemedicine systems. IEEE Transactions on Information Technology in Biomedicine, 4(3), 189-193. doi: 10.1109/TITB.2000.5956074 
Leal, S. A. (2009). Estado de saúde auto-percebido: Índice de massa corporal e percepção da imagem corporal em utentes dos cuidados de saúde primários (Dissertação de mestrado, Faculdade de Psicologia e Ciências de Educação, Universidade de Lisboa, Lisboa, Portugal).

Lee, K., Hoti, K., Hughes, J. D., \& Emmerton, L. M. (2015). Consumer use of "Dr Google": A survey on health informationseeking behaviors and navigational needs. Journal of Medical Internet Research, 17(12), e288. doi: 10.2196/jmir.4345

Limayem, M., Hirt, S. G., \& Cheung, C. M. (2007). How habit limits the predictive power of intention: The case of information systems continuance. MIS Quarterly, 31(4), 705-737. doi: $10.2307 / 25148817$

Luarn, P., \& Lin, H.-H. (2005). Toward an understanding of the behavioral intention to use mobile banking. Computers in Human Behavior, 21(6), 873-891. doi: 10.1016/j. chb.2004.03.003

Luo, X., Li, H., Zhang, J., \& Shim, J. P. (2010). Examining multi dimensional trust and multi-faceted risk in initial acceptance of emerging technologies: An empirical study of mobile banking services. Decision Support Systems, 49(2), 222-234. doi: 10.1016/j.dss.2010.02.008

Mackert, M., Mabry-Flynn, A., Champlin, S., Donovan, E. E., \& Pounders, K. (2016). Health literacy and health information technology adoption: The potential for a new digital divide. Journal of Medical Internet Research, 18(10), e264. doi: 10.2196/jmir.6349

Miltgen, C. L., Popovič, A., \& Oliveira, T. (2013). Determinants of end-user acceptance of biometrics: Integrating the "big 3 " of technology acceptance with privacy context. Decision Support Systems, 56, 103-114. doi: 10.1016/j.dss.2013.05.010

Neter, E., \& Brainin, E. (2012). eHealth literacy: Extending the digital divide to the realm of health information. Journal of Medical Internet Research, 14(1), e19. doi: 10.2196/jmir.1619

Norman, C. D., \& Skinner, H. A. (2006a). eHEALS: The eHealth literacy scale. Journal of Medical Internet Research, 8(4), e27. doi: $10.1525 / \mathrm{cmr} \cdot 2014 \cdot 57.1 .67$

Norman, C. D., \& Skinner, H. A. (2006b). eHealth literacy: Essential skills for consumer health in a networked world. Journal of Medical Internet Research, 8(2), 1-11. doi: 10.2196/ jmir.8.2.e9

Nunnally, J., \& Bernstein, I. (1994). Psychometric theory (3rd ed.). New York, USA: McGraw-Hill.

Oliveira, T., Faria, M., Thomas, M. A., \& Popovič, A. (2014). Extending the understanding of mobile banking adoption: When Utaut meets TTF and ITM. International Journal of Information Management, 34(5), 689-703. doi: 10.1016/j. ijinfomgt.2014.06.004

Ong, J. W., Poong, Y. S., \& Ng, T. H. (2008). 3G services adoption among university students: Diffusion of innovation theory. Communications of the IBIMA, 3(16), 114-121.

Rai, A., Chen, L., Pye, J., \& Baird, A. (2013). Understanding determinants of consumer mobile health usage intentions, assimilation, and channel preferences. Journal of Medical Internet Research, 15(8), e149. doi: 10.2196/jmir.2635
Research2guidance. (2016). mHealth App Developer Economics 2016. Retrieved from https://research2guidance.com/r2g/ r2g-mHealth-App-Developer-Economics-2016.pdf

Riffai, M. M. M. A., Grant, K., \& Edgar, D. (2012). Big TAM in Oman: Exploring the promise of on-line banking, its adoption by customers and the challenges of banking in Oman. International Journal of Information Management, 32(3), 239250. doi: 10.1016/j.ijinfomgt.2011.11.007

Riley, W. T., Rivera, D. E., Atienza, A. A., Nilsen, W., Allison, S. M., \& Mermelstein, R. (2011). Health behavior models in the age of mobile interventions: Are our theories up to the task? Translational Behavioral Medicine, 1(1), 53-71. doi: 10.1007/ S13142-011-0021-7

Ringle, C. M., Wende, S., \& Becker, J. M. (2015). SmartPLS 3: SmartPLS GmbH, Boenningstedt. Journal of Service Science and Management, 10(3). Retrivied from: https://www.scirp. org/journal/JSSM/

Shareef, M. A., Kumar, V., \& Kumar, U. (2014). Predicting mobile health adoption behaviour: A demand side perspective. Journal of Customer Behaviour, 13(3), 187-205. doi: 10.1362/1 $47539214 X_{14103453768697}$

Shields, M., \& Shooshtari, S. (2001). Determinants of selfperceived health. Health Reports - Statistics Canada, 13(1), 35-52. Retrieved from: https://pubmed.ncbi.nlm.nih. gov/15069807

Smith, M. S., Wallston, K. A., \& Smith, C. A. (1995). The development and validation of the perceived health competence scale. Health Education Research, 10(1), 51-64. doi: 10.1093/her/10.1.51

Steinhubl, S. R., Muse, E. D., \& Topol, E. J. (2015). The emerging field of mobile health. Science Translational Medicine, 7(283), 283rv3-283rv3. doi: 10.1126/scitranslmed.aaa3487

Sweileh, W. M., Al-Jabi, S. W., AbuTaha, A. S., Zyoud, S. H., Anayah, F. M. A., \& Sawalha, A. F. (2017). Bibliometric analysis of worldwide scientific literature in mobile - health: 2006 2016. BMC Medical Informatics and Decision Making, 17 (1), 72. doi: 10.1186/s12911-017-0476-7

Tan, P. J. B. (2013). Applying the Utaut to understand factors affecting the use of english e-learning websites in Taiwan. SAGE Open, 3(4), 1-12. doi: 10.1177/2158244013503837

Thong, J. Y., Hong, S. J., \& Tam, K. Y. (2006). The effects of postadoption beliefs on the expectation-confirmation model for information technology continuance. International Journal of Human Computer Studies, 64(9), 799-810. doi: 10.1016/j. ijhcs.2006.05.001

Tomás, C. C., Queirós, P. J. P., \& Ferreira, T. J. R. (2014). Análise das propriedades psicométricas da versão portuguesa de um instrumento de avaliação de e-Literacia em saúde. Revista de Enfermagem Referência, série IV(2), 19-28. Retrieved from http://www.scielo.gpeari.mctes.pt/scielo.php?script=sci arttext\&pid=S0874-02832014000200003\&lang=pt. doi: $10.12707 /$ riv14004 
Venkatesh, V., \& Morris, G. M. (2000). Why don't men ever stop to ask for direction? Gender, social influence and their role in technology acceptance and usage behaviour. MIS Quarterly, 24(1), 115-139. doi: 10.2307/3250981

Venkatesh, V., Morris, M. G., Davis, G. B., \& Davis, F. D. (2003). User acceptance of information technology: Toward a unified view. MIS Quarterly, 27(3), 425-478. doi: 10.2307/30036540

Venkatesh, V., Thong, J. Y. L., \& Xu, X. (2012). Consumer acceptance and use of information technology: Extending the unified theory of acceptance and use of technology. MIS Quarterly, 36(1), 157-178. doi: 10.2307/41410412
Wei, T. T., Marthandan, G., Chong, A. Y. L., Ooi, K. B., \& Arumugam, S. (2009). What drives Malaysian m-commerce adoption? An empirical analysis. Industrial Management \& Data Systems, 109(3), 370-388. doi: 10.1108/02635570910939399

World Health Organization. (2019). WHO guideline: Recommendations on digital interventions for health system strengthening. Geneva, Switzerland. Licence: CC BY-NC-SA 3.0 IGO.

Xin, X. (2004). A model of $3 \mathrm{G}$ adoption. AMCIS 2004 Proceedings. Paper 329, 2755-2762. Retrieved from http://aisel.aisnet.org/ amcis2004/329

\section{AUTHORS` CONTRIBUTIONS}

Nayra Martins, Paulo Duarte and José Carlos Pinho worked on the conceptualization and theoreticalmethodological approach. The theoretical review was conducted by Nayra Martins, Paulo Duarte and José Carlos Pinho. Data collection was coordinated by Nayra Martins, Paulo Duarte and José Carlos Pinho. Data analysis included Nayra Martins, Paulo Duarte and José Carlos Pinho. All authors worked together in the writing and final revision of the manuscript. 